\title{
NATIONALISM AND DEMOCRACY: A COMPARATIVE ANALYSIS OF ALLAMA IQBAL AND ABUL ALA MAWDUDI
}

\author{
Muhammad Amir*, Sultan Mahmood $\dagger$ \& Faraz Ali Shah $\ddagger$
}

\begin{abstract}
This paper tries to analyze the views of the two great Muslim leaders and scholars Allama Muhammad Iqbal, and Mawdudi especially on Nationalism and Democracy. Both have scholarly views on these issues. They were against the western concept of the nationalism and democracy and stated that these concepts are not in the favor of Muslims of the subcontinent and are against the Islamic principles. They opposed West minster democracy and nationalism. While they emphasised on the sovereignty of Allah and Islamic sharia, they argued that the narrow concept of nationalism based on boundaries, race, culture, language is against the Islamic concept of Ummah and not in favor of the future of the Muslims of the sub-continent. To find out the research problem secondary as well as primary sources are used in order to collect data.
\end{abstract}

Keywords: Mawdudi, Iqbal, Democracy, Nationalism, Sovereignty

\section{Introduction}

Although Allama Muhammad Iqbal and Abul Ala Mawdudi were two different personalities. Iqbal was the poet, philosopher, lawyer, leader, and

\footnotetext{
* Lecturer, Department of Pakistan Studies, Abbottabad UST.

$\dagger$ Associate Professor, Department of Pakistan Studies, Abbottabad UST.

\# PhD Scholar, Department of Pakistan Studies, Abbottabad UST.
} 
modern educationist while Abu Ala Mawdudi was the religious scholar, writer, Journalist, Sharia expert, and great politician. But their thoughts and views resemble each other's.

Allama Iqbal and Molana Mawdudi have some similarities they were both the reformers and did a lot of work for the Muslims and Pakistan. Both leaders had a lot of courage confidence and foresightedness. Both had praised the glorious history of Islam and thought in terms of Islamic revivalism, both were God loving and were very much worried about the future of Muslims in general and of Pakistan in particular. They considered Quran as the only remedy for the ailment of Muslim Ummah and took it the only guide for the time to come, and had a deep love for the Holy prophet (PBUH), though both had a pole apart educational origins, have similarities in their thinking and philosophy.

With his poetry, Allama Iqbal awakened the dormant Muslims of the sub-continent and reinvigorated in them the spirit of revivalism and Mawdudi took forward the spirit with his prose and founded an organized movement of revivalism in Muslims of the sub-continent. Iqbal and Mawdudi keenly observed Muslim's condition dispassionately and their minds were never static. Their thoughts and ideas constantly kept evolving till the last moment of their lives. They were great Muslim thinkers of the $20^{\text {th }}$ century. Their thoughts have deeply influenced our national ethos.

According to Syed Nazeer Niazi, Once Allama Iqbal told him that to him the most important dilemma is the restructuring of Islamic Jurisprudence. At present we are moving away day by day from Islam and the main reasons are the collective political issues which in the present situation are growing more and more complicated. Ulmma needed to understand and mold the situation according to the principle of Islam. Iqbal said that there is very valuable pamphlet late with the name of "Tarjumanul Quran" Published by Haider Abad Daken, Mawdudi as its editor. He has an eye on religious as well as on contemporary issues. Further Iqbal praised the book "AL jihad Fil Islam" written by Abul Ala Mawdudi.

In 1978, in an interview Molana Mawdudi stated that I have learned by heart the poem of Allama Iqbal in childhood. Slowly and gradually, my thoughts and opinion became like Iqbal. One day I received a letter from Iqbal. He wrote to me that you should shift to Punjab because in the coming days the Southern India will not remain a safe place to live. Although initially he did not agree with his opinion. Later, probably on $18^{\text {th }}$ or 19 April he shifted but on $21^{\text {st }}$ April Allama Iqbal died. 


\section{Nationalism and Iqbal}

Iqbal's view of Nationalism is flexible one but when it comes to European nationalism it gets hard. In his point of view the concept of nationality is a significant aspect in the development of communities. But it is appropriate to be overstated, and when overstated it has inclination to deform the broad human elements in art and literature.

"Iqbal profounded the idea of religious nationalism. He seems fully cognizant of the incompatible relationship between Islam and the idea of modern secular nationalism. Philosophically speaking the idea of 'Islamic nationalism' is quite contradictory. Islamic universality does not recognize the differences of race and geography stated by Iqbal. Nationalism, on the other hand, is a product of 'particular' circumstances of modern European history and destabilizes the foundation of universalism.

Iqbal offered the idea of religious nationalism,

During the initial period of Iqbal's life, he was so much actuated by his hatred of the British imperialism that he could not give a serious consideration to the practical implications of the theory of nationalism. Besides, he had yet to develop his own philosophy of life which he could use as a criterion of judgment between right and wrong. Iqbal's writings of this period include, among other writings, three main patriotic poems:

"Tarana-i-Hindi" (The Indian Anthem), "Hindustani Bachon Ka Qaumi Geet" (The National Song of the Indian children) and "Naya Shiwala" (The New Temple).These poems are innocent expressions of the natural patriotic feeling of an Indian and do not reflect his faith in nationalism as a philosophy of life. In these three poems, Iqbal urges upon his countrymen to forget their differences of caste and creed and work unitedly for the freedom and welfare of India:

$$
\begin{aligned}
& \text { مزبب نبيس سكها تا آيس ميس بير ركهنا }
\end{aligned}
$$

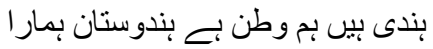

Religion does not preach mutual hatred;

We are all Indians and India is our motherland

In "Naya Shiwala", the poet, addressing a Brahmin, declares that the motherland itself is the new temple:

Your god is latent in the images of stone

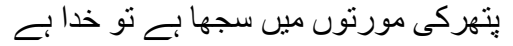

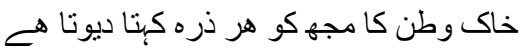

My god is every particle of my motherland's dust. 
All these poems were written before 1905. In 1905, Iqbal went to Europe for higher studies and this proved a turning point in his career in more than one way. He looked into the European socio-political conditions very carefully and found that materialism, imperils, and nationalism were destroying the vitals of Europe and leading it to a suicidal warfare. The holocaust of 1914-18 had started casting its shadows for those who possessed a discerning eye and, there is no doubt about the fact that Iqbal was one of them:

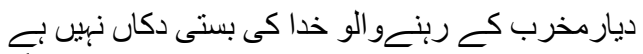

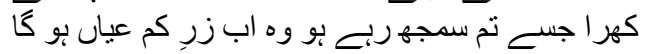

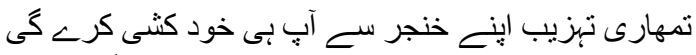

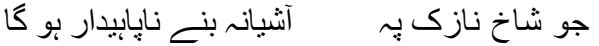

$O$ Westerners, God's World is not shopping center,

What you hold to be genuine and true will turn out false and counterfeit.

Your culture will stab itself to death;

Unstable is the nest built on precarious twig.

This was the time when Iqbal began to develop his own philosophy of life by rediscovering the validity of the principles of Islam for his age. After studying Iqbal's post-1905 literary and poetic works, it is revealed that he rejects nationalism on three main grounds:

1: It makes man earth bound and closes on him the doors of spiritual evolution. Man is neither a mere animal nor is the satisfaction of carnal desires his ultimate destiny. His noble spirit is meant for higher things than merely licking the dust of the earth. A philosophy which binds man to a particular piece of land acts like a clog on his spiritual progress.

2: It is antagonistic to the broader humanitarian ideal which Islam sets before man. It divides mankind on grounds of race, colour, language and nationality. This naturally gives rise to unhealthy rivalry between various nationalities struggling for superiority. To justify a nation's endeavors for its superiority it gives birth to misleading and inhuman philosophies like Hitler's Fascism which was based on the superiority of the Aryan race to all other races and justified the genocide of the Jews on this ground.

3: Nationalism gives rise to a competition among nations to a belief that a powerful nation has the right to subjugate or even to annihilate a weak nation. Aristotle wrote in the Politics (Book 1) that nature had created the barbarians (The Non Greeks) to serve as slaves and to wage war for the enslavement of such races is, therefore, justified. In their glorious 
days the Jews also believed that any crime was justified if the victim was a Gentile. Hitler echoes these sentiments in his book, My Struggle. 'Germany above all' is the essence of his thought, and Germans have this honor because they belong to the Aryan race. Likewise, the British Imperils considered the non-white races as 'the White man's burden'. The narrowing of outlook to which nationalism inevitably leads has an adverse effect on all aspects of human thought and action.

In the Reconstruction of Religious Thought in Islam, Iqbal writes: that "The growth of territorial nationalism with its emphasis on what is called national characteristics has tended Rather to kill the broad human element in the art and Literature of Europe".

Thus it becomes clear that according to Iqbal, nationalism is the cause of rivalry between nations, it is a means of subjugating weaker nations by powerful ones. Iqbal once again where he denounces nationalism in the spirit of religion:

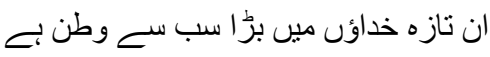

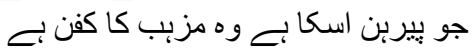

Among these innovative idols, the idol of nation is prominent, The fundamentals of which shrouds the religion

\section{Mawdudi Concept of Nationalism}

Like Allama Iqbal, Mawdudi was against the Western concept of nationalism which is based on Darwin's theory of the survival of the fittest, and transmitted into the social philosophy of the Human society. The modern concept of the nationalism has created hatred and animosity against each other's but also between the nations. The lust of the development and progress over the other nation has become the source of the misuse of the wealth and resources of the other nations. Resultantly the weak nations are colonialized by the powerful nations.

According to Mawdudi the Western concept of nationalism has four aspects, i.e prejudice, national superiority, their pride and interest. With cruelty the western nations have imposed their might on the weak nations to achieve these four goals. Mulana Mawdudi argued that the biggest curse on the humanity is the phobia of nationalism which is also dangerous for the human culture and race. 
Mawdudi criticized the concept of nationalism of the west and advised the Muslims not to follow the western concept unseeingly and advised to follow the Islamic principles of equality, justice, love and brotherhood. He also stated that we cannot compare Islam and nationalism with one another because these two are far apart concepts the development of one means the decay of other. "Muslim nationalist and Muslim communist are as contradictory terms as communist fascist, socialist capitalist, chaste prostitute. A Muslim in that capacity can't support nationalism, as the last is antithetic to the specific thought of Islam. As the Mawdudi stated;

"One ultimate goal of Islam is a world state in which the claim of racial and the national prejudices would be dismantled, and all mankind incorporated in a cultural and political system, with equal rights and equal opportunities for all."

Nationalism is a concept of dividing the humanity and encourages parochialism. It promotes reverence for a specific locality instead of humanism and humanity. It breeds intolerance for other territorial and ethnic nationals and causes aggression for imperialist domination of the rest of the nationalities of the world. In modern world it is great danger for the peaceful co-existence of different nationalities in stage of history. According to the modern concept of nationalism the national interest is the only end of the nationalism and can do anything to protect and promote its national interest.

Nationhood comes into being where there is a common nationality in part of world. Nationality in the sense is actually an "inflamed nationality". We may divide nationality into two types i.e. political and cultural nationality. The former type is existent in India due to the governance of the political system at the movement. Britian's rule has kept the people intact by their shared economic and social laws. It is a kind of nationhood which can function without any commonality traditions, language, religion and thoughts. However these things are not enough to give shape to nationalism. The later type is cultural nationality and is indispensible for making a nation. The second type of nationalism was missing in the case of pre-partitioned India because it requires unanimity in entirety of its members about the realities of life. The unanimity can be seen only in the people who socially, culturally, spiritually, morally and mentally have merged in one organic whole.

Mawdudi suggests two ways to make a single nation in India. The first way is that the mighty nationality conquers and assimilates the weaker nationalities and the second way is to evolve one nation by fusion of 
different cultures. The former suggestion is ruled out "because the supporters of composite nationality in India cannot form it their esteemed end". The second suggestion also cannot be practiced in India at present because it is impossible to practice it in a day or two rather it will take centuries in a natural way of evolution. He puts forward his own solution for solving the issue of nationalism in India in the following manner:

The individual status of each single nationality should be recognized. All of them should have sovereignty and autonomy in the control of the subject of its national importance. Furthermore, the divergent nationalities should create consensus upon the matters of common interests of the country as a whole.

\section{Iqbal Concept of Democracy}

Democracy is a political ideal according to which the sovereignty of a state, or a government should be in the hands of its people. Perhaps, this is why democracy as a political system was defined by a great democrat, Abraham Lincoln، in these words: "Democracy is a government of the people, for the people and by the people." Since the term 'demokratia' was coined in the 5th century B.C; until about a century ago, democracy was used as a political concept. In the 19th century, Charles Tocqueville (18051859), a French political historian, was first struck by the social aspect of American democracy, and thus he spoke of a 'social democracy' in his celebrated work De la Democratieen Amerique (1838-1840). He predicted that in the modern democracy his ideal of liberty would be sacrificed in the interests of equality.

The expression 'social democracy' usually points to the democratization of society itself and is expressed by its manners and customs and particularly by the belief in what Bryce called "equality of estimation", that is, equal treatment and equal respect for everyone. Later on, Marxism popularized the expression 'economic democracy' by emphasizing the economic equality of individuals in a socialist society. While James Webb's work on 'Industrial Democracy' (1897) has given currency to the label, 'Industrial Democracy', Iqbal in his attempt to reconstruct the religious thought in Islam, has given currency to a new term known as 'spiritual democracy'.

Iqbal frequently referred equality and democracy as synonymous with Islam, in his works. He rejected the concept of the unlimited powers of the king bestowed upon him by the God. He gives the instances of the Persian and English Kings. He rejected the title of Zill-i-Ilahi given to the Persian king in which the king is considered as the shadow of God on the earth. 
There is no such comparison made by Iqbal in his writings about the forms of government i.e anarchy, democracy, oligarchy, timocracy and aristocracy. However it is our own comprehension and understanding which guide us to transcend his writing by instinctively knowing his philosophy. This understanding leads us that the favorite kind government for Iqbal is neither democracy nor monarchy; rather it's the concept of timocracy presented by the Greek philosopher. Timocracy is a government by brave people. It is neither based on supreme knowledge as in the case philosopher kings in his ideal state nor based on aristocracy rather it is marked by honor and velour.

Iqbal was critical of the democratic organizations of the West only because it had used individuals as means to an end not as end in themselves. This aspect of the Western democracy did not appeal him. According to Iqbal, democracy fails to develop a right type of leadership and becomes a repressive influence arresting the growth of personality and freedom of individual. It is not better than a blind numerical counting of human heads, and consequently, political wisdom and justice are apt to become mere functions of a numerical majority. To him, the chief flaw of democracy is that it counts rather than weighs people. Inspired by a statement of Stendhal (1783-1842), a French novelist, Iqbal wrote:

$$
\begin{aligned}
& \text { اس راز كو ايكى مرد فرنكى نـ كيا فانش }
\end{aligned}
$$

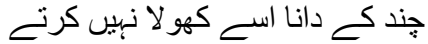

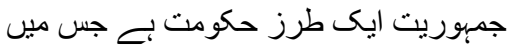

$$
\begin{aligned}
& \text { بندؤن كو كنا كرنـ بين نوز لا نبين كرنـ }
\end{aligned}
$$

A wise man of the West has exposed this secret

Even though every wise man does not usually do so.

Democracy is a form of Government in which

Men are merely counted and not weighed.

Broadcasting on the occasion of New Year's Day in 1938 Iqbal said:

"Modern age prides itself on its progress in knowledge and its matchless scientific developments. No doubt, the Pride is justified... but, in spite of all these developments, The tyranny of imperialism struts abroad, covering its face In the masks of democracy, Nationalism, communism, Fascism and heaven knows what else under besides."

Like Iqbal, several social thinkers of the East and the West were critical of democracy. For instance, Plato's famous work The Republic is too much critical of democracy. For Plato, a democracy that could accuse a man like Socrates of ruining public morals and of being an enemy to mankind, and 
force him to drink the cup of hemlock, could not be commended anyway. Similarly, according to German thinker, Nietzsche, democracy is a conspiracy of the masses and slave people, so that they may rule over the intellectuals and rare higher minds of the society. It is a way of life which prevents the growth of higher minds. Nietzsche was opposed to democracy, because, for him, it is a way of suppressing free men of higher type. Laws and morals in a democracy are based on the idea of human equality. According to him, religions like Christianity, which have encouraged the growth of the base and weak minded people, have been responsible for spreading this false notion that all men are equal. It is a manifest delusion to which facts of history lend no support. Evolution tends to the creation of men of a higher type who think differently from their contemporaries, whereas, religions and laws based on the idea of equality consider such persons to be a public menace and seek, in every possible way, to destroy them. Life has never made any progress by masses, but by the higher type of men. According to Nietzsche, if life had depended on the opinion of the masses, man would have remained lower than the lowest animals. Even in those political organizations which are apparently organized democratically, important decisions are made really by a few powerful individuals, while others follow them like sheep.

Iqbal, too, condemned democracy of the present era and exposed all its demerits at a time when the British imperialism and Western ideas were dominating like a magic spell all over the Eastern nations. However, Iqbal's criticism was not against democracy itself, but against its demerits only. As a matter of fact, Iqbal had a great love for democracy, but his notion of democracy was guided by the Muslim democracy and so it was somewhat different from the modern democracy of the West. In an essay "Sir Muhammad Iqbal and Fredric Nietzsche", Subash Kashyap has highly observed:

Iqbal's kingdom of God on earth means the democracy of more or less the most unique individuals possible. The rule of one wise man is better than that of an assembly of masses.... This superior man with his moral and intellectual forces is the most suitable person to guide the human society. The possibility of such development in a single individual is much more than in many. The decision of a group of people represents that of the average intellect.

In the Reconstruction, Iqbal concludes his essay "The Principle of Movement in the Structure of Islam" by saying: "Let the Muslims of today appreciate their position, reconstruct their social life in the light of ultimate principles, and evolve, out of the hitherto partially revealed purpose of 
Islam, that spiritual democracy which is the ultimate aim of Islam'14. In 1917, Iqbal discusses democracy with some ambivalence: "Democracy has a tendency to foster the spirit of legality. This is not in itself bad; but unfortunately it tends to displace the purely moral standpoint, and makes the illegal and wrong identical in meaning." In the following verses Iqbal sums up his views on democracy

$$
\begin{aligned}
& \text { تو نه ديكها نهبي مخرب كا جمهورى نظام }
\end{aligned}
$$

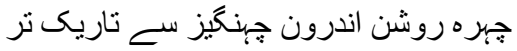

Haven't you observed the Western democratic system;

Apparently useful, but in reality tyrannical even than Changes.

The above verse surely reveals how critical Iqbal was against such a system of governance. He states that the form of rule will decrease the opportunities of purifying the qualitative features in the Muslim community. With the passage of time he became critical of almost all the ideologies of the west including democracy. He remarked just three month earlier his death:

Despite these happenings, the oppression of imperialism remained ensued abroad with the façade of Fascism, communism, nationalism and democracy and God is aware of many things more. With these facades on the surface of earth the dignity and freedom of humans are put under the foot which has no parallel even in the darkest episodes of human history. These governments, leadership and statesmen proved a cause of oppression, bloodshed and tyranny. He argues that territorial nationality is not a long lasting thing, the only thing which can be depended on, is brotherhood and unity. It is something above the race, language, color and nationality. If this so called nationalism, democracy and tainted system of imperialism are not doomed, so long the humans rejects it practically and express their views that the entire humanity is a family, so long the discrimination on the basis geographical nationalities, race and colour are not rooted out, the humans on the earth will be unable to lead a contented and happy life.

Iqbal is of the view that the democratic governments in the west has got the colour and shape of imperialism. Therefore they are unable to put an exemplary model in from of the Muslim world to be followed. Their concept of nation state, nationalism and secularism had made them unable to form a universal human integrating model in the world. However, these states consider themselves as model for the rest of the world.

According to the thoughts of Iqbal the west too is not happy with democracy in the future. Keeping the future demographic change which is 
visible in the west that is the white race is reproducing in a very sluggish rate, will become less in number and will automatically become minority in their own country after a generation or two. In such a democracy the western whites will be dominated by the coloured citizens having origin of nonwestern base, therefore the think-tanks of western societies are hesitant about the democratic future in the west while outside the west they are supporting dictatorship in the third world countries and especially the Muslim world. "Arguing about the relationship of democracy and imperialism, he believed that the imperial designs show that they are fed up of democracy. The feeling against the functioning of democratic rules in France and England is best example. Iqbal is indicating the period of war in Europe. His views are prophetic about the embryonic stage of democratic development in the western world. He criticized the pluralistic model of the state in the following words:

It characterized state as multi-national,

And thus covered its trickery under this naïve phrase. One can hardly move about freely in its environment, No door can be opened by its keys.

It said to the bird in cages' sorrow stricken bird, Build thy nest in the house of the hunter; He who builds his nest in meadows and gardens Cannot be secure from falcon and hawk.

As mentioned above, it seems apparent to us through the ethos of Iqbal that his notions of democracy, like nationalism, was merely an instrument of awakening Muslim masses and mobilize them for the sake of collective action. This is not a cardinal principle of Iqbal's world view.

Iqbal criticized certain aspects of democracy not because he was against it but he was keen to reform the concept of democracy in such a way that it could purge humanity of all evils and establish a social order that would be nearer to the concept of the "Kingdom of God on Earth." He saw the vision of democracy in Islam. Islam shifts the basics of the democracy from economic exploitation to a spiritual purification and better economic adjustment. Iqbal has criticized democracy and secularism as practiced and preached in the west in his collection named as Zarb-e-Kalim. In this collection in a place he argues that in democratic system of the west these are number of heads which have values not the brains inside these heads. In Paym-e-Mashriq he suggests the Muslims to keep aside from the western form of democracy. He believes that the brain of 200 asses cannot balance 
the mind of one man. He did not want to compromise and accept democracy on the basis of being the popular form of government. He argue that without competence a man can become popular. He gives his views to the western world through his writing Gulshan-e-Razz in which the Satan is left loose in the shape of secular democracy as a sharp sword at the disposal of political elite. Iqbal saw the giant of imperialism in the shape of democracy of the west. He proved the severe critic of the nationalistic, secular democracy and repeatedly referred to it in his verses as nothing more than imperialism. He termed democracy a ghost of oppression in democratic attire dancing and they are taking it as a fairy of independence. The only purpose of this system of government is the protection of the interest of rich at cost of exploitation of the poor. He believes that the civilization and institution erected on the basis of secular democratic system will not last long. He highlights the demerits of western capitalistic democracy and dialectic materialism. $\mathrm{He}$ argues that the class war is a byproduct of territorial concept of secular democratic nation state and tolerance, justice and harmony are the attributes Islamic democracy. Islam does not allow injustice with others nor does it allow the other to deal someone unjustly. He makes the analogy of democracy with a used coat which the European countries discarded after a trial but the countries of Asia are picking it up despite of its ill-fitness. After the study of secular democracy the philosopher of the west are clear that this form of government cannot fulfill the ends for which it was expected therefore they have to conform Iqbal's views.

\section{Mawdudi View of Democracy}

Maulana Mawdudi is totally against the western democracy, the principle of the western democracy is based on will of the majority people and the legal and political sovereignty rests in the hand of the people, while people free frame the laws of the state according to their own will and religion has no concern with state affairs and constitution. Beside this the concept of the Islam is very different from the western concept of democracy. Islamic democracy is based on the Shariah law, which is based on the Quran and Sunnah. The whole constitution is present in the Islam and Sunnah, men can only legislate the laws of light of sharia. The basic difference between western concept of democracy and Islamic democracy lies in the nature and role of the head of the state, i.e. the head of the western state works on the will of the people while the head of the Islamic state works on behalf of the God and act as per the Shariah (Quran and Sunnah). 
Molana Mawdudi writes about the Indian state and its nature of the democracy and secularism. This type of the state will be under the nonMuslim majority. The congress will impose their own rule and ignore the will of the Muslims. So this type of secularism and democracy is not acceptable to Muslims. He further writes that the western concept of the democracy divided the people of the state into the majority and minority, in which the minority are discriminated on the basis of race, language, and religion. The majority always tries to suppress the minority in such type of state which is based on the western concept of the state. Molana Mawdudi presented Islamic state as a democratic state, although he considers the Islamic state as opposite to the west ideas of state. But he considers the democracy as an alternative polity of Islam up to some extent. He did not reject the principle in totally but he was against some particular aspects of democracy. According to him, democracy with the concept of the secularism and nationalism becomes dangerous. Mawdudi considered that the Islamic democracy is against the secular western democracy especially the sovereignty of the people and uncontrolled authority of ruler. Democracy is treated as neutral ideal, which can be Islamized with following west, then democracy can be appreciated. Molana Mawdudi was against the democratic constitution because it is unable to protect the minority's rights, thus western democracy becomes the tyranny by majority and this kind of polity became the source of the huge threat to identity, culture and religion of minority. So Mawdudi called the democracy in the Indian context as posing threat to Muslims.

Molana Mawdudi have written in his book "the Islamic law and constitution" about people's concept of democracy and Islam. Some people consider that the Islam and democracy are same by this they mean to imply that there is no difference between Islam and democracy as in vague in the west.

According to Molana Mawdudi the main characteristics of Islamic state are following.

1: God alone is the real sovereign; all others are merely his subjects. No person, class or group, not even the entire population of state as a whole, can lay claim to sovereignty.

2: God is real law-giver and the authority of absolute legislation vest in Him. The believers cannot resort to totally independent legislation nor can they modify and any law which God has laid down, even if the desire to effect such legislation or change in Devine law is Unanimous

3: as Islamic state must, in all respects, be formed upon the law laid down by God through his prophet. The government which runs such a state 
will be entitled to obedience in its capacity as a political agency setup to enforce the laws of God and only in so far as it acts in that capacity. If it disregards the law revealed by God, its commands will not be binding on the believers.

\section{Conclusion}

Allama Muhammad Iqbal and Molana Abu Ala Mawdudi were the great scholars of the $20^{\text {th }}$ century. They strived hard for the revivalism of the Muslims of the sub-continent. Up to some extent they seemed agreeing with the western concept of democracy, while at some point they strongly criticized the same. The western concept of democracy makes the masses sovereign to rule their destinies, which is against the Islamic principles. They were also against the concept of western nationalism based on race, colour, creed, language, locality and religion. On the contrary they believed that the human lives are sacred to be cared by the Divine arrangement. They believed in the sovereignty of All-mighty Allah. They seemed uncompromising on the issue of making religion a private matter of an individual.

\section{References}

A. Rashid Moten, Pure and practical ideology: The thought of Mawlana Mawdudi The Islamic Quarterly,1984, pp. 217-240.

Abu Ala Mawdudi, Islami Riyasat (Lahore: Islamic Publication, 2016), p.243.

Charles J Adams, Mawdudi and the Islamic State :In Voices of resurgent Islam (n.p: Oxford University Press, 1983), pp. 99-133.

Hakim. K.A. Islam and communism (Lahore: Institute of Islamic culture, 1953), p. 31.

Harver Ready reference Encyclopedia (New York: n.p, 1969) p.552.

Harver, Ready reference Encyclopedia, p.552.

Iqbal Muhammad, Bal-i-jibril (Aligarh: Educational Book House,1975), p. 57.

Iqbal Muhammad, Bang-i-Dara (Lahore: Sh. Muhammad Ashraf \& sons, 1984), p. 55.

Iqbal Muhammad, Pas chi Bayadkard ay aqwam-i-sharq (New Delhi: Atiqad Publishers, 1975), p. 88.

Iqbal Muhammad, Stray Reflections (Lahore: Iqbal academy Pakistan, 2006), p. 86. 
Iqbal Muhammad, The Reconstruction of Religious Thought in Islam

(Lahore: Institute of Islamic Culture, 2003), p. 11.

Iqbal Muhammad, Zarb-i-kaleem (Lahore: Sh. Mubarak, Ali Book Sellers, 1934), p. 65.

Iqbal Muhammad, Zarb-i-Kaleem, p. 45.

Iqbal Nama, ed. By Shaikh Ataullah, Vol. 1, Lahore, p.318.

Iqbal, Muhammad, The Reconstruction of Religious thought in Islam (Lahore: Institute of Islamic Culture, 2003), p. 23.

Iqbal, Muhammad, The Reconstruction of Religious Thought in Islam (Lahore: Institute of Islamic Culture, 2003), p. 87.

Kashyap S, Sir Muhammad Iqbal and Fredric Nietzsche (London: Islamic Quarterly 1955), p.185.

Khan, Iqbal and Mawdudi, p.6.

M. Allama Iqbal and Molana Mawdudi, p.2.

M. Saleem, Allama Iqbal and Molana Mawdudi (Lahore: Islamic Publications Ltd, 2016), p.4.

Maulana Mawdudi, Islam Awr Jadid Mashi Nazriyat, p.21.

Maulana Mawdudi, Islami Nizam-I -Zindagi, pp.304-305.

Maulana Mawdudi, Maslah-i Qaumiyat, pp. 125-128

Mawdudi, Islami Riyasat, pp. 480-481.

Mawdudi, Islami Riyasat, pp. 540-542.

Muhammad Iqbal, Bang-i- Dara (New Delhi: Atiqad Publishers, 1975), p. 25.

Muhammad Iqbal, Stray Reflections (Lahore: Iqbal academy Pakistan, 2006), p. 79.

Naiz Ahmad, Iqbal in Politics (Lahore: Sang-e-Meel Publications, 1990), p.45.

New Year's message broadcast from all India radio, Lahore station January 1, 1938: Reconstruction of Muslim political thought, pp. 230-232.

Presidential address delivered at the annual session of All India Muslim conference, Lahore, March 21, 1932.

Sayed Vali Reza, Mawdudi And The Making of Islamic Revivalism (Karachi: Oxford University Press, 1964), p. 56.

Shervani Lateef Ahmad, Speeches, writings and statements of Iqbal (Lahore: Iqbal Accademy Pakistan, 1977), p. 78.

Siyasi Kashmakash, vol.II, pp. 126-127.

Siyasi Kashmakash, vol.II, pp.127-128.

Smith. W.C, Modern Islam in India (New Delhi: Mentor Books, 1946), p. 132. 
Syed Abul Ala Mawdudi, Islamic Law And Constitution (Lahore : Islamic publication, 1975). p.119.

Syyed Abul Ala Maududi, nationalism and India, pp.10-11.

Umar Hayat Khan, Iqbal and Mawdudi (Delhi: Markazi Maktaba Islami, 1951), P.3.

Waheed-uz-zaman, Towards Pakistan (Lahore: Publishers United Ltd, 1978), pp. 231-232.

ZaffarIshq Ansari, Iqbal and Nationalism: Iqbal Review (Karachi:Vol-2. No1. 1961), p. 6. 